\title{
Perustoimeentulotuen Kela-sitrto VALMISTELTIIN KIIREELLÄ JA ASIANTUNTIJATIETO JÄTETTIIN HYÖDYNTÄMÄTTÄ
}

\author{
Antti Halmetoja: YTM, Valtiontalouden tarkastusvirasto \\ Taina Rintala: OTT, VTT, Valtiontalouden tarkastusvirasto
}

antti.halmetoja@vtv.fi; taina.rintala@vtv.fi

Janus vol. 28 (2) 2020, 185-193

Vuoden 2017 alusta voimaan tullut toimeentulotukilain (1412/1997) muutos on ollut yksi merkittävimmistä sosiaaliturvajärjestelmään tehdyistä uudistuksista vuosikymmeniin. Uudistuksessa perustoimeentulotuen toimivalta siirtyi Kelalle ja kunnille jäi täydentävän ja ehkäisevän toimeentulotuen toimivalta. Samalla osa täydentävällä toimeentulotuella katettavista menoista siirrettiin perustoimeentulotukeen. Uudistus oli poikkeuksellinen, koska sillä siirrettiin toimeentulotuen toimivaltaa paikalliselta tasolta valtakunnalliselle tasolle. Uudistuksella myös erotettiin taloudellinen tuki ja palvelu toisistaan. Tämä vei sosiaaliturvaa eri suuntaan suhteessa käynnistettyyn sosiaaliturvan kokonaisuudistuksen tavoitteeseen - yhteensovittaa palvelut ja etuudet paremmin (VNK 2020).

Toimeentulotuen siirrosta Kelalle on keskusteltu 1980-luvun puolivälistä lähtien (STM 1997). Kuntien ja Kelan välillä on ollut myös erilaisia kokeiluja. Kokeiluissa joko kunnan työntekijä on toiminut Kelan toimipisteessä tai Kela on myöntänyt toimeentulotukea kuntien ohjeiden mukaan (STM 2014). Kokeilussa ei kokeiltu mallia, joka sisällöllisesti vastaa tehtyä uudistusta. Tehtyjä arvioita kokeilujen hyvistä ja huonoista puolista ei näin ollen voitu suoraan hyödyntää uudistuksen valmistelussa.
Kela-siirrossa ei ollut kysymys vain teknisluonteisesta toimeenpanon muutoksesta. Sillä jaettiin toimeentulotuen kokonaisuus "kahdelle luukulle" - paikallisella ja kansallisella tasolla toimeenpantavaksi. Uudistuksella siirrettiin huomattavasti yksilöllistä tarveharkintaa edellyttävä viimesijainen taloudellinen tuki lähemmäs ensisijaisia etuusjärjestelmiä. Samalla toimeentulotuki säilyi kuitenkin sosiaalihuoltoon kuuluvana viimesijaisena taloudellisena tukena.

Kela-siirron vaikutuksia on selvitetty eri tutkimuksissa (Eronen ym. 2019; Cammarano \& Sjöholm 2019; Kivipelto ym. 2019; Jokela ym. 2019; VTV 2020). Asiaa on käsitelty pääasiassa sosiaalityön, asiakkaiden, muiden viranomaisten ja kustannusten näkökulmista. Vähemmälle huomiolle on jäänyt, miten Kela-siirron valmistelussa toteutuivat hyvän lainvalmistelun periaatteet. Kirjoituksellamme tuomme näkökulman keskusteluun ja esitämme, että kiireinen lainvalmisteluprosessi ja asiantuntijatiedon hyödyntämättä jättäminen ovat yhteydessä edellä mainituissa tutkimuksissa raportoituihin uudistuksen vaikutuksiin. Käsittelemme ensin valmisteluprosessia ja sen aikataulua.Tämän jälkeen esittelemme analyysimme valmistelun eri vaiheissa tunnistetuista riskeistä ja niiden käsittelystä hallituksen esityksessä (HE 358/2014 
vp). Valmisteluprosessin aikataulutusta koskevat tiedot ja analyysissa käsitellyt riskit perustuvat lainvalmisteluvaiheen dokumenttiaineistoon ${ }^{1}$. Lopuksi pohdimme, miten käsittelemämme asiat ovat mahdollisesti vaikuttaneet Kelasiirron vaikutuksiin.

\section{LAKI VALMISTELTIIN KIIREELLÄ}

Toimeentulotukijärjestelmän uudistus toteutettiin nopealla aikataululla. Sosiaali- ja terveysministeriö asetti toimeentulotuen uudistamista selvittävän työryhmän toimikaudelle 15.8.2013-30.10.2014. Työryhmän tehtävänä oli muun muassa arvioida tuen rakennetta, tuen suhdetta sosiaalityöhön sekä toimeentulotukityön hallinnollisia prosesseja. Toimeentulotuen Kela-siirto nousi esille marraskuun lopulla, kun Jyrki Kataisen hallitus täsmensi rakennepoliittisen ohjelman toimeenpanoa ja ilmoitti arvioivansa toimeentulotuen siirtoa maaliskuun 2014 kehysriiheen mennessä. Tehtävää varten sosiaali- ja terveysministeriö asetti arvioryhmän pohtimaan toimeentulotuen laskennan ja maksatuksen siirtämistä Kelalle. Samalla keskeytettiin toimeentulotuen uudistamista selvittävän työryhmän työ (STM 2015).

Arvioryhmä luovutti arviomuistion (STM 2014) kehysriihen valmistelun taustaksi 14.3.2014. Muistiossa arvioitiin neljää vaihtoehtoista mallia, jotka rakentuivat työryhmässä käytyjen keskustelujen pohjalta. Arviot kohdentuivat perustoimeentulotuen myöntämiseen liittyvään kunnan ja Kelan välisen yhteistyön vaihtoehtoihin. Kaikissa malleissa täydentävän ja ehkäisevän toimeentulotuen toimeenpano säilytettiin kunnilla. Työryhmä ei ottanut kantaa, tulisiko toimeentulotuen nykyrakennetta ja sisältöjä muuttaa. Ryhmä ei myöskään ottanut kantaa, mikä arvioiduista malleista olisi paras vaihtoehto.

Arvioryhmän työn pohjalta sosiaalija terveysministeriö esitti, että perustoimeentulotuen laskenta ja maksatus siirretään Kelan tehtäväksi seuraavasti: Täydentävä ja ehkäisevä toimeentulotuki säilyvät kunnissa sosiaalityöntekijöiden tehtävänä. Kelan etuuskäsittelyssä varmistetaan asiakkaiden ohjaus sosiaalityöhön yhteisesti sovituin perustein. Toimeentulotuki säilyy hakemusten perusteella myönnettävänä, ei automaattisesti tulojen perusteella myönnettävä tukena. Perustoimeentulotukea normitetaan yhtenäisesti siten, että kuntakohtaiset erot vähenevät. (STM 2014.)

Huhtikuussa 2014 valtioneuvosto vahvisti perustoimeentulotuen Kela-siirron osana vuosille 2015-2018 tehtyä julkisen talouden suunnitelmaa. Tavoitteena oli, että siirtoa koskeva hallituksen esitys annetaan eduskunnalle jo syksyllä 2014. Sosiaali- ja terveysministeriön mukaan uudistuksen valmistelu hyvän lainsäädäntövalmistelun mukaisesti ei ollut toteutettavissa tavoiteajassa ja valmistelulle varattiin muutama kuukausi enemmän aikaa. Uudistuksen voimaantulon siirtämisen vuoden 2017 alkuun katsottiin kuitenkin antavan mahdollisuuden riittävälle lainvalmistelulle. Hallituksen esityksen valmisteluaikataulun pidentäminen muutamalla kuukaudella ei näytä kuitenkaan olleen riittävä, koska uudistusta koskevia lain pykäliä jouduttiin muuttamaan useaan kertaan (L 1107/2016; L 299/2016) jo ennen uudistuksen voimaantuloa. Uudistusta 
valmisteltiin sosiaali- ja terveysministeriössä laajassa sidosryhmäyhteistyössä. Siihen osallistui edustajia valtionvarainministeriöstä, oikeusministeriöstä, Kelasta, Suomen Kuntaliitosta,Valvirasta ja STM:stä.

Uudistuksen valmisteluprosessin yhteydessä järjestettiin kuulemistilaisuudet ns. kutsuperiaatteella. Kutsu lähetettiin vain niille tahoille, joihin esityksellä arvioitiin olevan vaikutusta. Tätä perusteltiin valmistelun nopealla aikataululla. Kuulemisen tavoitteena on muun muassa selvittää valmisteltavaan asiaan liittyvät erilaiset näkökohdat ja vaikutukset. Menettelyllä vahvistetaan myös kansalaisoikeuksien toteutumista ja sidosryhmien ohella tulisi kuulla myös kansalaisia. (Kuulemisopas, Finlex.) Kela-siirtoa valmisteltaessa näin ei kuitenkaan toimittu ja kuulemistilaisuus järjestettiin nopealla aikataululla suhteessa uudistuksen merkittävyyteen. Kutsu kuulemistilaisuuteen lähetettiin 13.11.2014 ja tilaisuus pidettiin 19.11.2014. Kuultavilla tahoilla oli vain noin viikko aikaa arvioida esitystä. Kuulemisen kohteena olivat luonnos pykälistä ja niitä koskevista perusteluista, jotka olivat osin keskeneräisiä.

Järjestettiin kuulemistilaisuutta tai ei, ovat kirjalliset lausuntopyynnöt pakollinen osa lainvalmisteluprosessia. $\mathrm{Ne}$ täytyy pyytää keskeisiltä sidosryhmil- tä. (Kuulemisopas, Finlex.) Kela-siirtoa koskevassa lainvalmisteluprosessissa kirjalliset lausunnot pyydettiin kuitenkin vain kahdelta oikeustieteen professorilta koskien ainoastaan kuntien rahoitusvastuiden perusteita. Heiltä ei pyydetty lausuntoa esimerkiksi siitä, onko lakiesityksellä liittymäkohtia perustuslaissa turvattuun yhdenvertaisuuteen. Lausuntoja ja kuulemistilaisuutta koskeva yhteenveto valmistui 30.12.2014. Hallituksen esitys (HE 358/2014 vp) annettiin eduskunnalle jo 23.1.2015. Aikataulusta voidaan päätellä, että luonnosta ei kuulemisten ja lausuntojen perusteella merkittävästi paranneltu. Eduskunta kävi esityksestä lähetekeskustelun 28.1.2015 ja päätti lähettää asian sosiaali- ja terveysvaliokunnan käsiteltäväksi. Sosiaali- ja terveysvaliokunta ei pyytänyt lausuntoja muilta valiokunnilta. Valiokunta kuuli asiantuntijoita ja pyysi kirjallisia lausuntoja. Valiokunnan mietintö (StVM 54/2014 vp) valmistui 6.3.2015. Eduskunta hyväksyi lakiehdotuksen 12.3.2015, ja laki tuli voimaan 1.1.2017. Lainvalmisteluprosessi ja sen aikataulu herättävät kysymyksen, olisiko Kela-siirron kaltaisen merkittävän muutoksen valmisteluun tullut käyttää enemmän aikaa. Kuviosta 1 nähdään uudistuksen valmistelun aikajana. 


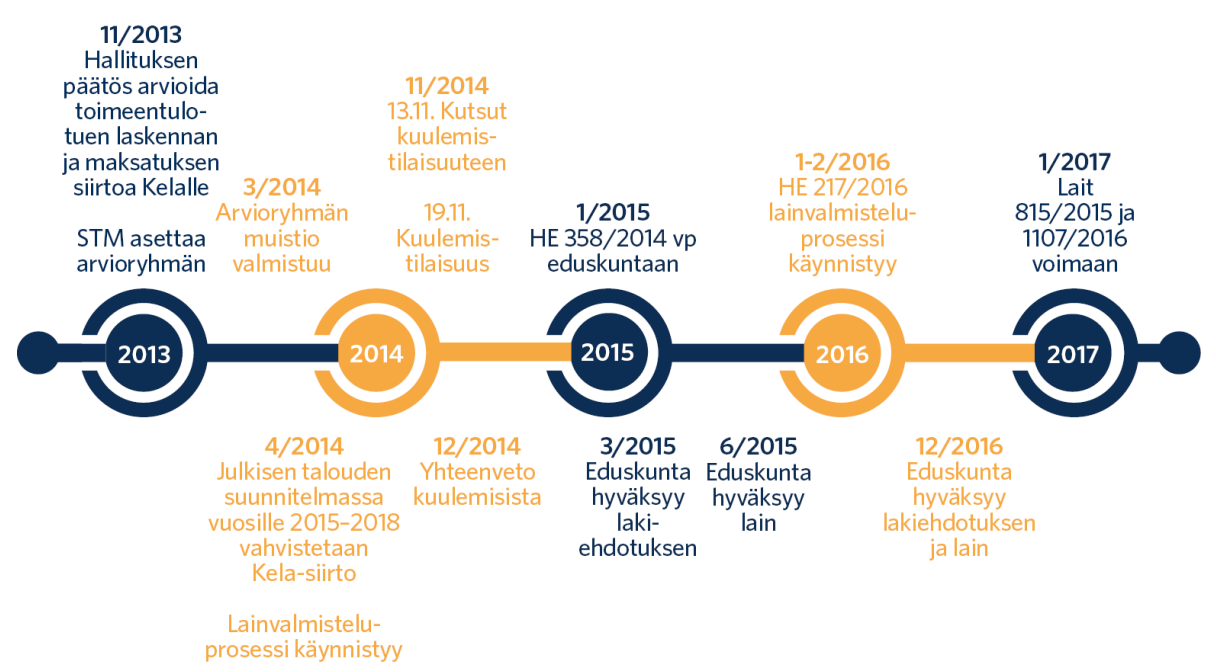

Kuvio 1. Kela-siirron valmisteluprosessi

\section{HaLlitukSEN ESITYKSESSÄ EI TEHTY AVOIMESTI SELKOA SEN RISKEISTÄ}

Hallituksen esitys toimii eduskunnalle päätöksenteon perustana. Siinä on tehtävä avoimesti selkoa ehdotetun lainsäädännön mahdollisista hyöty- ja haittavaikutuksista sekä niiden kustannuksista. (OM 2004.) Vaikutuksia arvioitaessa on pyrittävä tunnistamaan riskejä ja odottamattomia vaikutuksia siitä huolimatta, että ne voivat syntyä monien eri tekijöiden yhteisvaikutuksesta ja erilaisten vaikutusketjujen kautta (OM 2007). Valtiontalouden tarkastusviraston (2020) perustoimeentulotuen Kela-siirtoa koskevan tarkastuksen mukaan lainvalmistelussa tunnistettiin merkittäviä riskejä, mutta monet niistä jäivät käsittelemättä hallituksen esityksessä.

Tässä luvussa käsittelemme perustoimeentulotuen Kela-siirron lainvalmisteluvaiheissa tunnistettuja riskejä. Arvioimme, miten kattavasti tunnistet- tuja riskejä käsiteltiin ja ratkaistiin hallituksen esityksessä (HE 358/2014 vp). Uudistuksesta annettiin eduskunnalle myös toinen hallituksen esitys (HE $217 / 2016$ vp). Sillä paikattiin uudistusta koskeneeseen lakiin (L 815/2015) jääneitä puutteita ennen lain voimaantuloa. Rajaamme tarkastelun kuitenkin vain ensimmäisen hallituksen esityksen valmisteluprosessiin, koska sen perusteella uudistus hyväksyttiin.

Jaottelimme valmistelun kolmeen vaiheeseen. Ensimmäinen vaihe sisältää uudistuksen vaihtoehtoisia malleja arvioineen asiantuntijaryhmän muistion ja hallituksen esitysluonnoksesta annetut lausunnot. Toinen vaihe koskee eduskunnalle annettua hallituksen esitystä. Kolmas vaihe sisältää sosiaali- ja terveysvaliokunnan mietinnön sekä valiokunnan keräämät lausunnot. Keräsimme mainituissa dokumenteissa esiin nousseet riskit ja muodostimme niistä yhdeksän yleisempää riskikategoriaa. Hallituksen esityksen osalta ar- 
vioimme riskin tunnistamisen lisäksi, onko riski ratkaistu tai ratkaistu osittain. Näin pystyimme arvioimaan, miten hyvin Kela-siirtoa koskevassa lainvalmisteluprosessissa noudatettiin hallitusten esitysten laatimisohjeissa korostettua periaatetta haittavaikutusten avoimesta käsittelystä. Asiantuntijatiedon hyödyntämistä lainvalmistelun tukena pidetään yleisesti tärkeänä. Analyysimme perusteella Kela-siirron yhteydessä kerätty asiantuntijatieto jätettiin merkittäviltä osin hyödyntämättä.

Kela-siirron valmisteluvaiheessa tunnistetut riskit kohdistuivat pääasiassa asiakkaiden asemaan, toimeentulotukijärjestelmän toimeenpanon sujuvuuteen ja kustannuksiin, viranomaisten yhteistoimintaan sekä toimeentulotukilain tavoitteiden toteutumiseen. Osa analyysissa muodostetuista riskikategorioista tunnistettiin riskeiksi useista eri näkökulmista. Esittelemme lyhyesti neljä merkittävintä riskikategoriaa.

Toimeenpanon jakautuminen kahdelle luukulle

Toimeentulotuen jakautuminen kahden toimeenpanijan välille tunnistettiin riskiksi niin asiakkaiden aseman kuin viranomaistenkin näkökulmasta. Asiakkaiden näkökulmasta nähtiin, että osa joutuu uudistuksen myötä asioimaan toimeentulotukiasioissa kahdella luukulla. Tämän katsottiin pidentävän heidän toimeentulotukihakemuksensa kokonaiskäsittelyaikaa ja viivästyttävän tuen saantia. Riskin arvioitiin kohdistuvan erityisesti asiakasryhmiin, jotka hakevat sekä perustoimeentulotukea että täydentävää toimeentulotukea. VTV:n tarkastus osoitti, että hakemusten käsittely on pitkittynyt erityisesti sellais- ten asiakkaiden kohdalla, jotka hakevat ainoastaan täydentävää toimeentulotukea. Tämä johtuu siitä, että täydentävää toimeentulotukea haettaessa on oltava päätös perustoimeentulotuesta. (VTV 2020.)

Kahden luukun mallin riskiksi tunnistettiin myös se, että kunta ja Kela saattavat olla eri mieltä asiakkaan tilanteesta. Esimerkiksi asiakkaan perusosan alentamistapauksissa kunnalla ja Kelalla saattaa olla eriäviä näkemyksïä alentamisen perusteista. Lisäksi kahdelle luukulle jakautumisen arvioitiin vaikeuttavan erityisesti toimintakyvyltään heikentyneiden asiakkaiden asiointia. Hallituksen esityksessä kahden luukun malliin liittyviä riskejä ei kuitenkaan ratkaistu. Esityksessä todettiin, että perustoimeentulotuki turvaa asiakkaan välttämättömän toimeentulon, vaikka täydentävän tai ehkäisevän tuen käsittely saattaa pitkittyä.

\section{Sosiaalityö ja taloudellinen tuki eriytyvät}

Toimeentulotuen on katsottu perinteisesti kytkeytyvän vahvasti kunnassa tehtävään sosiaalityöhön. Sosiaalityö ja toimeentulotuki ovat sosiaalipalveluita (L 1301/2014). Sosiaalityön ja taloudellisen tuen välisen sidoksen heikkeneminen ja sosiaalityötä tarvitsevan asiakkaan tunnistamisen vaikeutuminen tunnistettiin riskiksi. Tämän katsottiin johtuvan siitä, että Kelan asiantuntijoilta puuttuu tai heillä on liian vähän sosiaalityön osaamista. Lisäksi arvioitiin, että sosiaalityön ja taloudellisen tuen eriytymisen myötä kuntien sosiaalityön välineet supistuvat. Perustoimeentulotuki on yksi väylä sosiaalityön asiakkuuteen, ja tämän väylän arvioitiin vaarantuvan. Riskiksi tunnistettiin 
myös se, että yhteyden heikkeneminen saattaa johtaa pitkittyneeseen toimeentulotuen asiakkuuteen ja heikentää toimeentulotukilain tavoitteiden saavuttamista.

Hallituksen esityksessä sosiaalityön ja taloudellisen tuen välisen sidoksen heikkeneminen tunnistettiin ja siihen liittyviä riskejä ratkaistiin korostamalla Kelan ohjaus- ja neuvontavelvollisuutta, Kelan ja kuntien yhteistyötä, Kelan virkailijoiden koulutusta sekä sähköisen järjestelmän kautta tehtyjä (Kelmu)ilmoituksia. Ratkaisematta kuitenkin jäi, millaisilla toimenpiteillä asiakkaat saadaan tosiasiallisesti hakeutumaan palvelujen piiriin. Asia korostui edelleen sosiaali- ja terveysvaliokunnalle annetuissa lausunnoissa. Tämä kertoo siitä, ettei riskiä ratkaistu riittävällä tavalla hallituksen esityksen luonnosvaiheessa saatujen lausuntojen perusteella. Voimaantulon jälkeen tämä on näkynyt muun muassa niin, että pitkäaikaisesti toimeentulotukea saaneiden osuus on kasvanut (Kivipelto ym. 2019), ja kunnissa sosiaalialan asiantuntijoiden työajasta osa kuluu asiakkaiden etsimiseen (Jokela ym. 2019; Kivipelto ym. 2019; VTV 2020).

\section{Heikoimmassa asemassa olevien asema heikkenee}

Toimeentulotuki on viimesijainen taloudellinen tuki ja tarkoitettu ensisijaisesti kaikkein heikoimmassa asemassa olevien turvaksi. Sitä uudistettaessa tulisi kiinnittää erityistä huomiota heikoimmassa asemassa olevien asiakkaiden asemaan. Lainvalmistelussa asiaan kiinnitettiinkin huomiota eri näkökulmista. Katsottiin, että uudistus voi laskea heikoimmassa asemassa olevien toimeentulotuen tasoa tilanteissa, joissa menot eivät ole tarve- ja kohtuullisuusharkinnan edellyttämiä tai eivät sovi perusmenoihin. Erityistä huomiota kiinnitettiin asioinnin mahdolliseen vaikeutumiseen, jolla viitattiin sähköisen asioinnin korostumiseen, toimeentulotuen kokonaisuuden jakautumiseen kahdelle luukulle ja perustoimeentulotuen asiakkaiden palveluihin ohjautumiseen. Hallituksen esityksessä riskiksi tunnistettiin kuitenkin ainoastaan sen varmistaminen, että asiakkaat ohjataan ja ohjautuvat oikeaan viranomaiseen. Ratkaisuksi esitettiin sähköisen järjestelmän kautta lähetettyjä ilmoituksia ja perustoimeentulotuen päätösten kautta tapahtuvaa ohjausta.

Tarveharkinnan ja yhdenvertaisuuden $y h$ teensovittaminen on vaikeaa

Valmistelun eri vaiheissa tuotiin esiin, että toimeentulotuki on viimesijainen ja yksilöllistä tarveharkintaa edellyttävä tuki. Asiantuntijat korostivat tarveharkintaan ja toisaalta tarveharkinnan sekä yhdenvertaisuuden yhteensovittamiseen liittyviä asioita, jotka tulisi huomioida ja ratkaista uudistuksen valmistelussa. Arvioryhmän (STM 2014) viesti oli, että perustoimeentulotuki sisältää tarveharkintaa edellyttäviä elementtejä ja jos ne säilytetään, yhdenvertaisuutta ja henkilöstöresurssisäästöjä ei tulla saavuttamaan tavoitellussa laajuudessa.Yksilöllistä tarveharkintaa ei ole mahdollista normittaa ja harkintaa edellyttävän hakemuksen käsitteleminen on työläämpää kuin puhtaasti laskennallisen hakemuksen. Esiin tuotiin myös se, että yksilöllisen tarveharkinnan toimeenpano edellyttää sosiaalityön osaamista. 
Valmisteluvaiheessa esitettiin, että perustoimeentulotuen sisällöt tulisi määritellä tarkemmin lainsäädännössä, jolloin sen sisältö olisi yksiselitteisempi ja suhde täydentävään toimeentulotukeen selkeämpi. Yksilöllisen tarveharkinnan ja yhdenvertaisuuden problematiikan olennaisuudesta huolimatta asiaa ei käsitelty hallituksen esityksessä, vaan perustoimeentulotukeen päätettiin lisätä harkintaa edellyttäviä elementtejä täydentävästä toimeentulotuesta.
Taulukossa 1 esitetään yhteenveto analyysimme tuloksista. Tulokset osoittavat, että uudistuksen varhaisessa valmisteluvaiheessa ja sosiaali- ja terveysvaliokunnan käsittelyssä tunnistettiin laajalti erilaisia riskejä. Hallituksen esityksessä valtaosa riskeistä jäi kuitenkin tunnistamatta ja tunnistettujen riskien ratkaisut olivat osittaisia. Tulos viittaa siihen, ettei eduskunnalle tehty avoimesti selkoa uudistuksen riskeistä.

Taulukko 1. Uudistukseen liitettyjen riskien tunnistaminen lainvalmisteluprosessin eri vaiheissa

\begin{tabular}{|c|c|c|c|}
\hline Riskit & Valmistelu & HE & Sote-valiokunta \\
\hline $\begin{array}{l}\text { Toimeenpanon jakautuminen } \\
\text { kahdelle luukulle }\end{array}$ & $\begin{array}{l}\text { asiakas- ja } \\
\text { viranomaisnäkökulma } \\
\text { tunnistettu }\end{array}$ & $\begin{array}{l}\text { asiakasnäkökulma } \\
\text { tunnistettu, ei ratkaistu; } \\
\text { viranomaisnäkökulma } \\
\text { tunnistettu, ei ratkaistu }\end{array}$ & $\begin{array}{l}\text { asiakas- ja } \\
\text { viranomaisnäkökulma } \\
\text { tunnistettu }\end{array}$ \\
\hline Kelan palvelujen saavutettavuus & tunnistettu & tunnistettu, osin ratkaistu & ei tunnistettu \\
\hline $\begin{array}{l}\text { Kiireellisen toimeentulotuen } \\
\text { käytännöt }\end{array}$ & tunnistettu & tunnistettu, osin ratkaistu & tunnistettu \\
\hline $\begin{array}{l}\text { Sosiaalityö ja taloudellinen tuki } \\
\text { eriytyvät }\end{array}$ & tunnistettu & tunnistettu, osin ratkaistu & tunnistettu \\
\hline $\begin{array}{l}\text { Henkilöstöresurssisäästöjä on } \\
\text { vaikea saavuttaa }\end{array}$ & tunnistettu & ei tunnistettu & tunnistettu \\
\hline $\begin{array}{l}\text { Heikoimmassa asemassa } \\
\text { olevien asiakkaiden asema } \\
\text { heikkenee }\end{array}$ & tunnistettu & tunnistettu, osin ratkaistu & $\begin{array}{l}\text { tunnistettu, } \\
\text { ratkaistava }\end{array}$ \\
\hline $\begin{array}{l}\text { Kaikilla ei ole edellytyksiä } \\
\text { sähköisen hakemiseen }\end{array}$ & tunnistettu & ei tunnistettu & tunnistettu \\
\hline $\begin{array}{l}\text { Tarveharkinnan ja } \\
\text { yhdenvertaisuuden } \\
\text { yhteensovittaminen on vaikeaa }\end{array}$ & tunnistettu & ei tunnistettu & tunnistettu \\
\hline $\begin{array}{l}\text { Perusosan alentamisen } \\
\text { käytännöt }\end{array}$ & tunnistettu & tunnistettu, osin ratkaistu & tunnistettu \\
\hline
\end{tabular}




\section{Pohdinta}

Toimeentulotuen uudistus toteutettiin varsin pikaisella aikataululla. Toimeentulotuen siirrosta kunnilta Kelalle oli keskusteltu viimeksi 2000-luvulla sosiaaliturvan uudistuskomitean mietinnössä (STM 2009). Komitea ei kuitenkaan tehnyt esitystä asiasta, koska asiasta ei vallinnut yksimielisyyttä (HE 358/2014 vp). Päätös Kela-siirrosta tuli yllätyksenä, koska poliittinen yksimielisyys löytyi ilman julkisuudessa käytyä keskustelua, valmistelutyötä ja erilaisten mallien kokeiluja.Yksi vaihtoehto sosiaaliturvaa uudistettaessa olisikin edetä joko alueellisten kokeilujen kautta tai vaiheittain. Tämä mahdollistaisi mallien vertailun ja hyvien sekä huonojen puolien arvioinnin. Arviointitiedon perusteella saatettaisiin järjestelmän uudistamisen sijaan päätyä muokkaamaan voimassa olevaa lainsäädäntöä toimivammaksi (VTV 2013).

Kela-siirto hyväksyttiin keskeneräisenä. Hallituksen esityksessä ei esitetty ratkaisuja esimerkiksi siihen, miten kiireellinen toimeentulotuki järjestetään tai miten heikoimmassa asemassa olevien asiakkaiden tarpeista huolehditaan. Sosiaali- ja terveysvaliokunta korosti mietinnössään (StVM 54/2014 vp), että edellä mainitut asiat tulee ratkaista ennen toimeenpanoa. Uudistusta muokattiinkin (L 1107/2016) jo ennen sen voimaantuloa. Vastuu hallituksen esityksen laadusta on lakia valmistelevalla ministeriöllä. Laadunvarmistus tapahtuu kuitenkin hallituksen esitystä käsittelevässä valiokunnassa. Se voi ehdottaa muutoksia käsiteltävänä olevaan esitykseen tai ehdottaa sen palauttamista valmisteluun (EKJ 2015).

Kela-siirto jakoi toimeentulotuen kokonaisuuden kahdelle luukulle. Tämä muutti perustoimeentulotuen ja täydentävän toimeentulotuen välisen rajan aiempaa ratkaisevammaksi asiakkaiden ja viranomaisten näkökulmista. Ennen Kela-siirtoa epäselvyyksiä perustoimeentulotukeen tai täydentävään toimeentulotukeen sisällytettävistä menoista ei muodostunut yhtä herkästi. Riski viranomaisten eriävistä näkemyksistä tunnistettiin valmisteluvaiheessa, mutta siitä huolimatta eri toimeentulotuen lajien sisältöjä ei tarkennettu säädännön keinoin.

Lainsäädännön valmistelun, päätöksenteon ja toimeenpanon pitäisi pohjautua tutkittuun tietoon. Tutkitulla tiedolla vahvistetaan päätöksenteon tietopohjaa ja parannetaan päätöksenteon laatua ja vaikuttavuutta (VNK 2013). Perustoimeentulotuen Kela-siirtoa koskevassa lainvalmisteluprosessissa olemassa olevaa tietoa hyödynnettiin kuitenkin valikoiden. Valmisteluvaiheessa tuotiin esille riskejä, joita ei kuitenkaan käsitelty lopullisessa hallituksen esityksessä. Hallituksen esityksessä riskejä ratkaistiin myös keinoilla, jotka ratkaisivat riskin vain osittain tai loivat uusia riskejä. Hallituksen esityksessä käsittelemättä jääneet riskit näyttävät olevan myös sellaisia, joiden toteutuminen on osaltaan lisännyt perustoimeentulotuen toimeenpanosta aiheutuvia kustannuksia ja vaikuttanut myös muiden toimeentulotukiasiakkaiden kanssa toimivien viranomaisten työhön (VTV 2020).

Suomessa sosiaaliturvan kokonaisuudistusta valmistelemaan on asetettu nyt parlamentaarinen komitea. Sen toimikausi kestää kaksi hallituskautta. Nähtäväksi jää, tuoko komiteatyö ratkaisuja ongelmiin, jotka liittyvät tiedon hyö- 
dyntämättä jättämisen ja liian kireän aikataulun ongelmiin.

\section{VIITE}

1 Aineisto koostuu Kela-siirron (HE $358 / 2014$ vp) lainvalmisteluvaiheen asiakirjoista. Näitä ovat valtioneuvoston dokumentit, asiantuntijoista koostuneen arvioryhmän muistio, hallituksen esityksen luonnos, luonnokseen saadut kirjalliset lausunnot ja kuulemistilaisuuteen toimitetut kirjalliset lausunnot, kuulemistilaisuuden yhteenveto, sotevaliokunnan mietintö, valiokunnan keräämät lausunnot ja STM:n muistiot ja päätökset koskien valmisteluprosessin etenemistä.

\section{KirjallisuUs}

Cammarano, Eveliina \& Sjöholm, Mari (2019) Toimeentulotuen ja aikuissosiaalityön tilanne kunnissa 2018. Uutta Kunnista 4. Suomen Kuntaliitto. http://shop. kuntaliitto.fi/product_details.php? $\mathrm{p}=3592$. Luettu 18.2.2020.

EKJ (2015) Valiokuntaopas 2015. Julkaisu 1. Eduskunnan kanslia. https://www.eduskunta.fi/FI/naineduskuntatoimii/julkaisut/Documents/ekj_1+2015.pdf. Luettu 18.2.2020.

Eronen, Anne \& Londén, Pia \& Peltosalmi, Juha (2019) Sosiaalibarometri 2019. Helsinki: SOSTE.

HE 358/2014 vp Hallituksen esitys eduskunnalle laeiksi toimeentulotuesta annetun lain ja kunnan peruspalvelujen valtionosuudesta annetun lain muuttamisesta.

Jokela, Merita \& Kivipelto, Minna \& Ylikännö, Minna (2019) Toimeentulotuelta sosiaalityön asiakkaaksi. Sosiaalityöhön ohjaaminen Kelan ja kunnan rajapinnassa. Työpaperi 26. THL. http://urn.fi/ URN:ISBN:978-952-343-392-2. Luettu 19.2.2020.

Kivipelto, Minna \& Tanhua, Hannele \& Jokela, Merita (2019) Selvitys toimeentulotukiuudistuksen vaikutuksista. Raportti 11. Helsinki:THL.

L 1107/2016 Laki toimeentulotuesta annetun lain muuttamisesta.
L 1301/2014 Sosiaalihuoltolaki.

L 1412/1997 Laki toimeentulotuesta.

L 299/2016 Laki toimeentulotuesta annetun lain muuttamisesta annetun lain 14 e $\mathbb{S}: n$ muuttamisesta.

L 815/2015 Laki toimeentulotuesta annetun lain muuttamisesta.

OM (2004) Hallituksen esitysten laatimisohjeet. Julkaisu 4. Helsinki: Oikeusministeriö.

OM (2007) Säädösehdotusten vaikutusten arviointi. Ohjeet. Julkaisu 6. Helsinki: Oikeusministeriö.

STM (1997) Toimeentulotukikokeilu 1995-1996. Loppuraportti. Selvityksï 5. Helsinki: Sosiaali- ja terveysministeriö.

STM (2009) Sosiaali- ja terveysministeriö. Sosiaaliturva uudistamiskomitean (SATA) ehdotukset sosiaaliturvan uudistamiseksi. Selvityksiä 62. Helsinki: Sosiaali- ja terveysministeriö.

STM (2014) Arvio toimeentulotuen laskennan ja maksatuksen siirrosta Kansaneläkelaitokselle. Arviomuistio. Helsinki: Sosiaalija terveysministeriö.

STM (2015) Toimeentulotuen uudistamista selvittäneen työryhmän loppuraportti. Raportteja ja muistioita 28. Helsinki: Sosiaalija terveysministeriö.

StVM 54/2014 vp Sosiaali- ja terveysvaliokunnan mietintö hallituksen esityksestä HE 358/2014 vp.

Säädösvalmistelun kuulemisopas. http://kuulemisopas.finlex.fi/. Luettu 19.2.2020.

VNK (2013) Valtioneuvoston periaatepäätös valtion tutkimuslaitosten ja tutkimusrahoituksen kokonaisuudistukseksi 5.9.2013. https://vnk.fi/ documents/10616/1034423/vnpvaltion-tutkimuslaitosten-ja-tutkimusrahoituksen-kokonaisuudistukseksi-05092013.pdf/. Luettu 19.2.2020.

VNK (2020) Tulevaisuuden sosiaaliturva. https://vnk.fi/tulevaisuuden-sosiaaliturva/ peruspilarit. Luettu 8.2.2020.

VTV (2013) Lainvalmistelun laatu ja kehittämistarpeet. Selvitys 3. Valtiotalouden tarkastusvirasto. www.vtv.fi. Luettu 17.2.2020. VTV (2020) Perustoimeentulotuen siirto Kelalle: Toimeenpanon vaikutusten arvioinnin merkitys lainvalmistelussa. Tuloksellisuustarkastuskertomus 1. Valtiontalouden tarkastusvirasto. www.vtv.fi. Luettu 10.2.2020. 